\title{
Cultivation-independent establishment of genetically engineered plants in natural populations: current evidence and implications for EU regulation
}

\author{
Andreas Bauer-Panskus ${ }^{1}$, Broder Breckling ${ }^{2,3}$, Sylvia Hamberger ${ }^{4}$ and Christoph Then $^{5^{*}}$
}

\begin{abstract}
About 20 years after the market introduction of the first GM plants, we review whether or not uncontrolled spread occurred. We summarise cases documented in the scientific literature and derive conclusions for the regulation of the authorisation of new events. Several cases documented in North and Central America and Japan show that transgenes have spread beyond cultivation areas. Important examples are bentgrass (Agrostis stolonifera), oilseed rape (Brassica napus) and cotton (Gossypium hirsutum). Several factors can be identified as relevant for transgene dispersal in the environment. Grasses (Poaceae), in particular, show a high potential for persistence and invasiveness, and wild relatives that can cross with the crop plants are a major factor in the unintended spread of the transgenes. There are significant uncertainties in predicting which transgenes will escape and how they will interact with the environment. For example, climate change is likely to have a major impact on the invasive potential of some plant species. The uncontrolled spread of transgenes is therefore a remaining challenge for regulators. We discuss some of these issues in the context of EU regulations since these regulations explicitly refer to the precautionary principle in the assessment of uncertainties. We found the that the precautionary principle as established in EU Directive 2001/18 can only be applied where efficient measures are available to remove genetically engineered organisms from the environment should this become necessary. If a removal from the environment would not be practically feasible, undesirable developments could not be mitigated.
\end{abstract}

Keywords: Precautionary principle; Transgenes; Persistence; Invasiveness; Gene flow; EU regulation; Centres of origin; Agrostis stolonifera; Brassica napus; Gossypium hirsutum

\section{Review \\ Introduction}

There have been many known cases of transgenes moving into the environment since the large-scale commercialisation of genetically engineered plants started around 20 years ago. Ellstrand [1] or Marvier and van Acker [2] provide an overview of the history of many such cases. Due to the circumstance that the vast majority of cultivated plants are not genetically isolated from the populations of wild relatives, there was a high likelihood that transgenes could not be 'kept on leash' [2]. Our review investigates whether there is evidence that

\footnotetext{
* Correspondence: christoph.then@testbiotech.org

${ }^{5}$ Testbiotech, Frohschammerstr. 14, Munich 80807, Germany

Full list of author information is available at the end of the article
}

transgenes have actually moved into natural populations. We survey results of according field research and discuss factors favouring gene flow. According to these factors, we identified additional cases where transgene escape is likely to occur in the future. Further, we explore the need for regulatory initiatives, especially in regard to the precautionary principle. Though we briefly address issues such as transgenic contamination of seeds and the food chain, we focus on the presence of genetically engineered cultivars and their offspring that can carry transgenes outside areas of intended presence, either as feral plants or as introgression into wild populations. We do not examine socio-economic effects, such as 
those relevant to crop purity, organic agriculture and trait segregation in food production. These issues would require a separate investigation as a follow-up to this review.

\section{Evidence that transgenes have escaped from agricultural fields}

We examined publications referring to various regions where genetically engineered plants are grown, both within and outside of the EU and in particular considering regions where wild relatives are native and thus genetically engineered plants might introgress into natural populations.

We concluded that there is sufficient scientific evidence to show that genetically engineered creeping bentgrass (Agrostis stolonifera) has escaped spatio-temporal control in the US. Gene flow to the related species Polypogon monspeliensis has occurred. Further, we concluded that there is a high likelihood of gene flow into natural populations from transgenic cotton (Gossypium hirsutum) in Mexico and transgenic oilseed rape (Brassica napus), at least in Canada and Japan.

We did not include cases such as the contamination of cultivated regional maize varieties and landraces in Mexico (see for example [3,4]). These cases are causing a high level of concern because Mexico is the centre of origin and diversity for this crop. However, since maize populations mainly occur in cultivation and outcrossing from transgenic maize to wild relatives (such as teosinte) under field conditions is not published in the literature, these cases do not fall under the selection criterion applied for the three case studies in this review, which focuses on persistence in wild populations.

\section{Case study: creeping bentgrass in the US}

In 2002, the Scotts Company (Marysville, OH, USA) started field trials with genetically engineered creeping bentgrass (A. stolonifera) in central Oregon (USA) near the city of Madras. The 2002 field trial comprised an area of 160 ha. In 2004, it was found that transgenes from bentgrass which had been made tolerant to herbicides containing glyphosate as the active ingredient had introgressed into wild growing bentgrass populations via pollen flow [5]. Outcrossing in wild bentgrass populations and the sexually compatible species Agrostis gigantea took place at distances of up to $14 \mathrm{~km}$; crosspollination by using trap plants was even found at a distance of $21 \mathrm{~km}$ [5]. In 2003, a storm caused widescale dispersal of transgenic bentgrass pollen. Attempts to remove all genetically engineered plants failed. During the years that followed, transgenic bentgrass was found all over the investigated area [6]. Tests conducted along irrigation canals showed that more than half of the investigated plants contained the glyphosate tolerance gene cp4epsps [7]. Currently, transgenic bentgrass can be found along irrigation canals, in roadside ditches, grassland and in fields. Genetically engineered bentgrass also escaped from a second field trial in Idaho [8]. Several years after the end of the field trial, transgenic plants were found in Canyon County (Idaho) as well as Malheur County in nearby Oregon. Apparently, transports were the reason for the dispersal [8]. According to a recent publication, even interspecific hybridisation with related species takes place. Hybrids were identified as rabbitfoot grass ( $P$. monspeliensis) that had introgressed into feral transgenic bentgrass [9]. Bentgrass is a perennial plant with many compatible related species [10]. Bentgrass as well as several relatives has invasive traits and are considered to be weeds [5,11]. Field trials in the 1990s have shown that herbicide tolerance genes can introgress into related species like Agrostis canina, Agrostis capillaris or Agrostis castellana [12]. A. stolonifera is wind-pollinated and produces large amounts of low-weight pollen. Up to 100,000 pollens per square meter were detected at a 2- to $3-\mathrm{km}$ distance from bentgrass fields [13]. Propagation may also take place by stolons [14]. An additional problem in the US bentgrass case is the fact that Oregon is the main production area for bentgrass seeds [14]. Bentgrass seed from Oregon is also exported to the EU and to other regions [15].

\section{Case study: transgenic cotton in Mexico}

Mexico and India are the centres of origin for cotton species, which are the basis for nearly all commercial cotton varieties cultivated today. In Mexico, wild cotton (G. hirsutum) populations are found mainly in the coastal regions of the southern states. Based on genetic differences, eight metapopulations can be distinguished. In a pilot study published in 2011 [16], Wegier et al. were able to show that transgene constructs from genetically engineered cotton have spread into these populations. Genetically engineered cotton has been planted in Mexico since 1996. According to industry sources, 161,500 ha of herbicide-tolerant and Bt cotton varieties were grown in 2011 [17]. The vast majority of commercially grown transgenic cotton is cultivated in Northern and Central Mexico, several hundred kilometres away from the regions where wild cotton is found. Nevertheless, every fourth sample proved positive for one or more transgenic constructs, and half of the populations were affected by transgenic introgression. In many - but not all - cases, the affected spots were located in relative geographical proximity of regions where some genetically engineered cotton is grown. There were also positive samples in locations more than $750 \mathrm{~km}$ away from transgenic cotton fields. In several samples, stacked constructs with up to four transgenes were found which are not present in any commercialised genetically engineered cotton event worldwide. Therefore, it can be 
assumed that several individual transgenes have hybridised with each other over time and have spread further within the wild cotton populations. The question of how these transgenes disperse in the wild populations is interesting: Cotton is considered to be mainly autogamous, and outcrossing via pollen is relatively rare $[18,19]$. Nevertheless, there are experimental results showing that pollination by honey bees and bumble bees can increase cotton yields [20] and pollinators contribute to extent and distance of outcrossing [18,19,21]. Outcrossing has been measured at distances of up to $1,625 \mathrm{~m}$ [21]. Thus, the findings of Wegier et al. [16] showing that outcrossing has taken place are not entirely surprising. A potential cause for the spread of transgenic cotton could probably be the transport of cotton seed from the USA, which is used as livestock feed. US cotton seed is not milled before export to Mexico and thus remains fertile. Nevertheless, it is not yet fully understood how transgenes introgressed.

\section{Case study: oilseed rape in Canada and Japan}

Canada was the first country to approve the commercial cultivation of genetically engineered herbicide-tolerant oilseed rape. Currently, herbicide-tolerant oilseed rape is grown on eight million hectares in Canada [22].

Main cultivation areas are the provinces of Manitoba, Alberta and Saskatchewan. The spread of genetically engineered oilseed rape became public when a study claimed that nearly all of the conventional Canadian seed supply of oilseed rape contained transgenes [23]. Several studies published later on found that throughout the main cultivation areas, feral populations had developed along the edges of fields and roadsides [24-26]. Japan receives a significant part of Canada's oilseed rape exports [27-29]. So, seeds have to be transported over long distances to Canadian overseas ports (e.g. Vancouver). Unsurprisingly, wild-growing populations of herbicide-tolerant oilseed rape were found around Vancouver [24]. Eighty-eight percent of feral oilseed rape populations examined in the province of Manitoba contained glyphosate-tolerant traits [25]. Eighty-one percent of the plants were tolerant to glufosinate. About $50 \%$ of the plants were tolerant to both herbicides. According to the authors, the populations are self-sustaining. In a follow-up to this study [26], it was found that 93 out of 100 tested feral oilseed rape plants growing along field edges or on roadsides in Manitoba were positively tested for transgenic constructs. Feral genetically engineered oilseed rape is also present in Québec [30]. According to this publication, all feral populations that were tested contained hybrids with Brassica rapa. Persistence of such hybrid populations over time was confirmed [31]. A long-term survey showed that feral hybrid populations of $B$. napus $\times$ B. rapa had decreased fitness, but nonetheless persisted over six consecutive years. Spread of transgenes by way of $B$. rapa is probable in eastern Canada because of the extensive cultivation of commercial varieties of this Brassica species [32].

In Japan, the cultivation of oilseed rape is of only minor importance [29]. However, there is large-scale cultivation of related Brassica species such as B. rapa and Brassica juncea [29] which easily hybridise with oilseed rape [33]. The cultivated forms of the two species are used as root or leafy vegetables. Both species are present as wild species or feral forms of cultivated varieties. For example, monitoring of the port areas showed that feral oilseed rape coexists with wild populations of $B$. juncea [28]. About $90 \%$ of the two million tons that are imported to Japan each year are from Canada [27,28]. The first studies on the presence of transgenic oilseed rape in Japan were published in 2005 [34]. Plants that proved resistant to glyphosate or glufosinate were found in the proximity of ports like Kashima, Chiba, Nagoya and Kobe as well as along transportation routes to industrial sites where oilseed rape is processed. Transgenic oilseed rape plants that had hybridised with each other and were tolerant to both herbicides were detected [35]. Follow-up studies found feral populations along other transportation routes [29] and in areas close to all other major ports $[28,36]$. Obviously, the percentage of transgenic oilseed rape in feral populations is constantly growing. In 2008, 90\% of all tested plants in the proximity of the port of Yokkaichi were found to be genetically engineered. The first hybrid between $B$. napus and $B$. rapa was found in Yokkaichi [35]. In addition, it was found that the properties of feral transgenic oilseed rape plants have changed under the influence of climatic conditions. From an ecological perspective, it should be of some concern that plants with greater height were found. These plants have also become perennial [28].

This is a major change in the biology of the plants, as oilseed rape and all other Brassica species cultivated in Japan are annual. Perennial forms of oilseed rape might have a significant impact on population dynamics. Perennial plants could potentially have a higher probability of spreading their genetic condition because they persist for a longer period. This could be seen as a factor supporting a higher fitness.

The centre of origin of the Brassica genus is assumed to be in the Mediterranean region. Based on a complete combination of two genomes (B. rapa $\times$ Brassica oleracea), B. napus occurs mainly as a cultivated plant, but still maintains significant characteristics of a wild plant. Disturbed soil promotes the establishment of B. napus beyond the fields, whereas dense vegetation will hinder establishment [37]. However, wild-growing B. napus is found primarily in habitats where wild relatives of the Brassica genus and related genera grow [37]. Also, many 
related species which can hybridise with oilseed rape occur in environments such as road verges, industrial sites or feral sites [37]. Gene flow to wild relatives is possible and likely to happen, even if $B$. napus itself only has a reduced potential to spread in a densely vegetated environment.

\section{Survey of other related cases of gene flow}

From existing data, it can be concluded that maize (Zea mays) in Mexico [3,4,38-41] and oilseed rape (B. napus) in the USA [42], Australia [43,44] and Europe [45-47] are likely to have escaped regulatory control, but it is unclear to which extent gene flow to wild relatives has already occurred. Finally, in the cases of rice (Oryza sativa) in China $[48,49]$, black poplar (Populus nigra) in China [50-52] and papaya (Carica papaya) in Thailand [53], it can be expected that transgenes will introgress natural populations, though evidence is not yet available. Relevant publications are summarised in Table 1. Other cases such as Vitamin A rice (Golden Rice) in the
Philippines which are likely to cause gene flow into the environment were not included, since quantitative gene flow investigations and publications are not available.

\section{Conditions favouring the escape of transgenes}

In many cases, a higher degree of domestication will lead to a lower potential to survive under natural conditions [54]. However, some domesticated grasses (Poaceae) still have a high potential for persistence and invasiveness. The history of rice provides some useful examples in this context: Rice was domesticated twice after a period of de-domestication [55]. Creeping bentgrass in the USA is a further example [5-9]. This issue is highly relevant in the context of agrofuels, where grass species with a high degree of invasiveness such as Miscanthus (Miscanthus $x$ giganteus) and switchgrass (Panicum virgatum L.) are cultivated. In the case of sorghum (Sorghum sp.) which has wild weedy relatives within the group of Poaceae, this is an issue that needs to be considered [56,57]. Finally, genetically engineered rice such as the so-called

Table 1 Overview of case studies of uncontrolled spread of genetically engineered plants ( $\mathbf{n} . \mathrm{i}_{\text {. }}=$ not investigated)

\begin{tabular}{|c|c|c|c|c|c|c|c|}
\hline Plant species & Country & $\begin{array}{l}\text { Commercial } \\
\text { cultivation }\end{array}$ & $\begin{array}{l}\text { Cases in } \\
\text { field } \\
\text { sites }\end{array}$ & $\begin{array}{l}\text { Cases } \\
\text { beyond } \\
\text { field sites }\end{array}$ & $\begin{array}{l}\text { State of } \\
\text { research }\end{array}$ & $\begin{array}{l}\text { Likelihood of persistence and } \\
\text { invasiveness in the regions concerned }\end{array}$ & References \\
\hline $\begin{array}{l}\text { Creeping } \\
\text { bentgrass (Agrostis } \\
\text { stolonifera) }\end{array}$ & USA & No & n.i. & Yes & $\begin{array}{l}\text { Confirmed by } \\
\text { several } \\
\text { publications }\end{array}$ & $\begin{array}{l}\text { Very likely to persist and invade because } \\
\text { bentgrass shows invasive potential }\end{array}$ & [5-9] \\
\hline $\begin{array}{l}\text { Black poplar } \\
\text { (Populus nigra) }\end{array}$ & China & Yes & Yes & n.i. & $\begin{array}{l}\text { Conclusive } \\
\text { studies still } \\
\text { missing }\end{array}$ & $\begin{array}{l}\text { Only very few investigations about potential } \\
\text { gene flow into wild poplar }\end{array}$ & $\begin{array}{l}{[50,51]} \\
\text { overview in } \\
{[52]}\end{array}$ \\
\hline $\begin{array}{l}\text { Cotton (Gossypium } \\
\text { hirsutum) }\end{array}$ & Mexico & Yes & n.i. & Yes & Pilot study & $\begin{array}{l}\text { Very likely to persist because of gene flow } \\
\text { into wild relatives }\end{array}$ & {$[16]$} \\
\hline $\begin{array}{l}\text { Maize/corn (Zea } \\
\text { mays) }\end{array}$ & Mexico & No & Yes & n.i. & $\begin{array}{l}\text { Confirmed by } \\
\text { several } \\
\text { publications }\end{array}$ & $\begin{array}{l}\text { Persistence very likely because of informal } \\
\text { seed exchange and the gene flow } \\
\text { between fields }\end{array}$ & {$[3,4,38-41]$} \\
\hline $\begin{array}{l}\text { Oilseed rape } \\
\text { (Brassica napus) }\end{array}$ & Australia & Yes & Yes & Yes & $\begin{array}{l}\text { Conclusive } \\
\text { studies still } \\
\text { missing }\end{array}$ & No conclusive publications & {$[43,44]$} \\
\hline $\begin{array}{l}\text { Oilseed rape } \\
\text { (Brassica napus) }\end{array}$ & Canada & Yes & Yes & Yes & $\begin{array}{l}\text { Confirmed by } \\
\text { several } \\
\text { publications }\end{array}$ & $\begin{array}{l}\text { Persistence and further spread very likely } \\
\text { because of confirmed gene flow to related } \\
\text { species }\end{array}$ & {$[23-26,30-32]$} \\
\hline $\begin{array}{l}\text { Oilseed rape } \\
\text { (Brassica napus) }\end{array}$ & Europe & No & n.i. & Yes & $\begin{array}{l}\text { Relevant studies } \\
\text { are mostly } \\
\text { missing }\end{array}$ & $\begin{array}{l}\text { No information about crosses into wild } \\
\text { relatives yet }\end{array}$ & {$[45-47]$} \\
\hline $\begin{array}{l}\text { Oilseed rape } \\
\text { (Brassica napus) }\end{array}$ & Japan & No & No & Yes & $\begin{array}{l}\text { Confirmed in } \\
\text { several } \\
\text { publications }\end{array}$ & $\begin{array}{l}\text { Gene flow into related species likely to have } \\
\text { occurred }\end{array}$ & {$[27-29,34-36]$} \\
\hline $\begin{array}{l}\text { Oilseed rape } \\
\text { (Brassica napus) }\end{array}$ & USA & Yes & Yes & Yes & Pilot study & $\begin{array}{l}\text { No information about crosses into wild } \\
\text { relatives. Unnoticed gene flow with wild } \\
\text { species is likely. }\end{array}$ & {$[42]$} \\
\hline $\begin{array}{l}\text { Papaya (Carica } \\
\text { papaya) }\end{array}$ & Thailand & No & Yes & n.i. & $\begin{array}{l}\text { Conclusive } \\
\text { studies still } \\
\text { missing }\end{array}$ & $\begin{array}{l}\text { Gene flow into de-domesticated papaya } \\
\text { could cause persistence }\end{array}$ & {$[53]$} \\
\hline Rice (Oryza sativa) & China & No & Yes & n.i. & $\begin{array}{l}\text { Conclusive } \\
\text { studies still } \\
\text { missing }\end{array}$ & $\begin{array}{l}\text { Persistence is likely due to informal seed } \\
\text { exchange and gene flow with weedy rice }\end{array}$ & {$[48,49]$} \\
\hline
\end{tabular}


Golden Rice [58] grown in regions where weedy rice populations exist is likely to show a substantial potential for gene flow and persistence as well as invasion of other rice fields. One important reason for this is permanent gene flow between the cultivated and the weedy rice $[59,60]$.

There are also examples which show that hybrids between wild and domesticated plants surprisingly show a higher degree of fitness than wild relatives and can even display invasive qualities: The wild coconut has been completely replaced by cultivated varieties [61]. Another important example in the USA is a spontaneous hybrid between wild radish (Raphanus raphanistrum) and cultivated (Rapahanus sativus) radish, which developed invasive hybrids. The so-called California wild radish shows a higher degree of fitness than the two parental species [62].

The probability of transgenes spreading uncontrolled into the environment can be increased if gene flow occurs into related, non-domesticated species which are known to be self-sustaining [63-66]. Wild species, from which our agricultural plants originate, and wild relatives do exist - at least at regional level - for all relevant crop plants. In this context, the centres of origin with a high degree of genetic diversity are of specific concern [67]. These are the regions where the agricultural varieties were originally domesticated. Gene flow, persistence and proliferation of transgenes in these regions are fostered by several factors. The plants are adapted to the environmental conditions in these regions and can cross with wild relatives. In many of these regions, there are established informal systems for seed exchange among small farmers that can lead to unnoticed transferrals of contaminated seeds. There are several examples showing that genetically engineered plants have already arrived in the centres of origin (for available literature, see Table 1; no publications available on field trials with 'Golden Rice'):

- Bt maize (corn) in Mexico

- Bt and herbicide-tolerant cotton in Mexico

- Bt rice in China

- 'Golden Rice' in the Philippines

- Bt poplar in China.

\section{Environmental risks}

There is a considerable and partly irreducible uncertainty about potential environmental concern and potential damage which could be caused by an uncontrolled spread of transgenes. Some risks are obvious:

- The control of weedy species can become more complicated with the proliferation of genetically engineered plants with herbicide tolerance. This could increase the pesticide use in the environment and the shift to more toxic substances. It can lead to higher workload for farmers and to an increase in operational costs.

- Genetically engineered organisms, which are no longer allowed on the market for economic or ecological reasons, cannot be removed efficiently if they proliferate in the environment. They can also contaminate harvests and cause substantial economic damage.

- The biodiversity in the centres of diversity is an important genetic resource for plant breeding. Future plant breeding might be hampered substantially if transgenes spread into these resources.

According to Snow et al. (2005), the following environmental risks have to be taken into account [68]: (1) creating new or more vigorous pests and pathogens; (2) exacerbating the effects of existing pests through hybridization with related transgenic organisms; (3) harm to non-target species, such as soil organisms, non-pest insects, birds, and other animals; (4) disruption of biotic communities, including agroecosystems; and (5) irreversible loss or changes in species diversity or genetic diversity within species.

In general, the overall long-term impact on ecosystems is hard to predict. In this regard, transgenic plants can be compared to alien species. Even if the biological characteristics of a species are known, its potential to persist or invade under new environmental conditions very often cannot be predicted [69]. Some of the alien species only persist in distinct local regions and do not spread substantially over a longer period of time (i.e. lag phase), but even after many years, they may still become invasive. It is also difficult to predict the ecological impacts of invasiveness [69]. The fact that climate change and disturbed ecological systems can foster invasiveness [70] could cause even further uncertainty.

The comparison between the spread of genetically engineered organisms and the invasive potential of alien species also shows major differences. In the case of genetic engineering, one must consider both the adaption and spread of a new species within an ecosystem and the spread of technically inserted genetic information within the pool of genes of a species that has already adapted to its environment. The dynamics of proliferation within established species can be different from the pattern of the ecological potential of alien species within a new environment.

In the context of genetic engineering, specific attention should be given to the genetic stability and functionality of the inserted DNA. Unlike alien species, genetically engineered crops contain technical DNA constructs, very often composed from elements such as 
promotors and stop codons, that are not subject to the natural self-regulation of gene expression in the plant cells. Under the influence of climate change or in their interaction with other stress factors, this can have unexpected effects in the crops [71-73] that may also imply new risks for the environment.

Consequently, it is very difficult to predict the longterm ecological impact of transgenes that escape spatio-temporal control, and it may be exacerbated by genetic re-arrangements and newly occurring mutations in combination with environmental (biotic as well as abiotic) changes. Therefore, risk assessment must take evolutionary dimensions into account. Evolutionary processes make it possible to turn events with a low probability of ever happening into events that may feasibly happen [74].

For example, outcrossing into wild species could be enhanced by climate or other environmental change. There are cases published showing that especially hybrids of cultivated species with wild species develop a higher fitness under stress [75]. A higher amount of gene flow for oilseed rape under extreme climatic conditions was reported [76]. The study shows that there was a change in the time for flowering, resulting in matching of flowering between species.

\section{Precaution, spatio-temporal control and EU regulatory aspects}

Where there are uncertainties, the precautionary principle provides a rational management strategy for the admission of transgenes. In the EU, the precautionary principle is part of the regulatory system. It has to be taken into account before decisions on experimental release or commercial cultivation are made (EU Directive 2001/18) [77]. The European Food Safety Authority (EFSA) is in charge of implementing this requirement. That is why we have chosen the EU regulation and its implementation by EFSA as the background for the discussion on whether the release of genetically engineered plants into the environment can be allowed if they cannot be controlled in spatio-temporal dimension.

In this context, it is important to understand that environmental risk assessment in the $\mathrm{EU}$ is an iterative process. If new information on the genetically engineered plants and their effects on human health or the environment becomes available, the risk assessment may need to be readdressed in order to determine whether the risk characterisation has changed and whether it is necessary to amend the risk management. The EU Directive 2001/18 foresees the monitoring of environmental impact (Article 20), and the admission of a specific GMO has to be renewed after 10 years. Its outcome should indicate whether the genetically engineered organism can remain on the market or whether the authorisation should expire (Article 17). Articles 8 and 23 cover cases where stopping the release of a genetically engineered plant may be deemed a matter of urgency immediately after new information about risks becomes available.

In conclusion, the EU can allow the import, release and commercial growing of plants inheriting transgenes. However, there is a caveat. If new information becomes available, the authorisation can be revoked. Then, the release of the transgenes must be terminated. However, if genetically engineered plants have escaped spatiotemporal control by dispersing in natural self-sustaining populations, they might no longer be retrievable as stipulated [78]. Thus, it needs to be discussed how genetically engineered organisms of different categories are to be regulated which

(a) can persist and invade the environment if they unintentionally escape their containment;

(b) have a high likelihood of persisting and spreading for a longer period of time, with or without crossing with wild relatives;

(c) have a known probability to become invasive after release into the environment.

Persistence and invasiveness are crucial for risk assessment as performed by EFSA [79]. However, clear regulatory criteria are missing on how to deal with genetically engineered organisms, which are likely to be impossible to retrieve from the environment [78]. The EFSA Guidance for environmental risk assessment [79] does not foresee the rejection of applications for genetically engineered plants, just because they are persistent and/or invasive. In fact, EFSA does not consider these biological characteristics to be a risk per se. The application is only likely to be rejected if it is already known at the time of the application that that the genetically engineered plant will lead to a reduction in biodiversity or impair ecological functions: The risk assessment should conclude on (1) the impact of the GM plant and/or hybridising relatives in the production system, particularly through increased weediness and more intense weed control; (2) the impact of the GM plant and/or hybridising relatives in semi-natural and natural habitats, through change in invasiveness or reduction of biodiversity or ecological function; (3) why any anticipated harm may be considered acceptable; and (iv) what risk management measures may be required to mitigate any harm. [79], p.49.

This seems to be in conflict with the precautionary principle and EU Directive 2001/18. As previously mentioned, the EU Directive 2001/18 foresees that emergency measures must be taken if new information is made available about serious risks (Article 8 and Article 23). Furthermore, market authorisation has to be 
monitored and reassessed after 10 years (Article 15.4 and Article 17). If there is new information on adverse impacts, the market authorisation can be terminated. If a genetically engineered organism no longer has authorisation, it must be removed from the market (Article 4 (5)) - and thus also from the environment. The release of genetically engineered organisms which cannot be controlled in spatio-temporal dispersal conflicts with these provisions. The precautionary principle as established in Directive 2001/18 is operational only if efficient measures exist that can assure the removal of the genetically engineered organism from the environment is feasible if required becomes a matter of urgency. Therefore, spatio-temporal control is a prerequisite for implementing precaution.

This finding is not only relevant for the EU. We believe that, in general, precautionary measures are an appropriate and necessary answer to the uncontrolled spread of transgenic plants. The regions where this is happening should discuss introducing the precautionary regulation in this context in order to protect biodiversity on the long term.

\section{Conclusions}

There is scientific evidence that GM plants exist which have escaped spatio-temporal control and introgressed into natural populations. The centres of origin of the respective plants are amongst the regions of particular concern.

Measures should be taken immediately to reduce uncontrolled further spread of transgenes into the environment. In the midterm, adequate regulations should be put in place that will prevent new problems in this context.

The cases as documented highlight current gaps in knowledge and make stricter regulation imperative in regard to experimental releases, transport and commercial cultivation of genetically engineered organisms if

(a) they can persist and invade the environment after unintentional escape from containment;

(b) there are major doubts about whether the transgenes can be retrieved from the environment within a reasonable period of time if urgency requires;

(c) it is already known that the transgenes will persist and/or show invasive behaviour after release into the environment.

\section{Competing interests}

The authors declare that they have no competing interests.

\section{Authors' contributions}

ABP lead in the literature research and in drafting the manuscript. BB was involved in drafting the manuscript, reviewing it and adding references on oilseed rape and maize. SH was involved in the conception and interpretation of findings. CT was involved in the conception and regulatory aspects. All authors read and approved the final manuscript.

\section{Authors' information}

ABP is acting as a search analyst for Testbiotech, a non-profit organisation in Munich, Germany, dealing with independent impact assessment in the field of biotechnology. He is also working as consultant for various institutions. BB is a senior scientist at the Chair for Landscape Ecology, University of Vechta and a senior lecturer at the University of Bremen, Centre of Environmental Research and Sustainable Technology (UFT), Bremen, Germany. Ecological modelling and impact assessment of large-scale cultivation of genetically engineered plants is one of his topics. He co-organised the GMLS - International Conference on Implications of GM Crop Cultivation at Large Spatial Scales. SH is working for the Society of Ecological Research, a non-profit organisation in Munich, Germany. One of her fields of interest is introgression of alien species and its impact. CT is acting as the executive and science dir ector for Testbiotech, a non-profit organisation in Munich, Germany, dealing with independent impact assessment in the field of biotechnology.

\section{Acknowledgements}

The publication is part of a project of Testbiotech that is funded by Gregor Louisoder Umweltstiftung, Munich.

\section{Author details}

${ }^{1}$ epigen, Frohschammerstr. 14, Munich 80807, Germany. 'Landscape Ecology, University of Vechta, Driverstrasse 22, Vechta 49377, Germany. ${ }^{3}$ UFT Centre of Environmental Research and Sustainable Technology, University of Bremen, Bibliothekstrasse 1, Bremen 28359, Germany. ${ }^{4}$ Gesellschaft für Ökologische Forschung, Frohschammerstr. 14, Munich 80807, Germany. ${ }^{5}$ Testbiotech,

Frohschammerstr. 14, Munich 80807, Germany.

Received: 18 August 2013 Accepted: 30 November 2013

Published: 19 December 2013

\section{References}

1. Ellstrand NC: Over a decade of crop transgenes out-of-place. In Regulation of Agricultural Biotechnology: The United States and Canada. Edited by Wozniak CA, McHughen A. The Netherlands: Springer; 2012:123-135.

2. Marvier M, Van Acker RC: Can crop transgenes be kept on a leash? Front Ecol Environ 2005, 3(2):99-106

3. Quist $D$, Chapela $\mid H$ : Transgenic DNA introgressed into traditional maize landraces in Oaxaca, Mexico. Nature 2001, 414:541-542.

4. Dyer G, Serratos-Hernández A, Perales H, Gepts P, Piñeyro-Nelson A, Chávez A, Salinas-Arreortua N, Yúnez-Naude A, Taylor JE, Alvarez-Buylla ER: Dispersal of transgenes through maize seed systems in Mexico. Plos One 2009, 4(5):e5734.

5. Watrud LS, Lee EH, Fairbrother A, Burdick C, Reichman JR, Bollman M, Storm M, King GJ, Van de Water PK: Evidence for landscape-level, pollenmediated gene flow from genetically modified creeping bentgrass with CP4 EPSPS as a marker. Proc Natl Acad Sci USA 2004, 101(40):14533-14538.

6. Reichmann JR, Watrud LS, Lee EH, Burdick C, Bollmann MA, Storm MJ, King GA, Mallory-Smith C: Establishment of transgenic herbicide-resistant creeping bentgrass (Agrostis stolonifera) in nonagronomic habitats. Mol Ecol 2006, 15(13):4243-4255.

7. Zapiola ML, Campbell CK, Butler MD, Mallory-Smith CA: Escape and establishment of transgenic glyphosate-resistant creeping bentgrass Agrostis stolonifera in Oregon, USA: a 4-year study. J Appl Ecol 2008, 45(2):486-494.

8. Mallory Smith C: Glyphosate resistant creeping bentgrass: same song second verse. In Proceedings of the Annual Meeting of the Western Society of Weed Science 2011: March 7-10 2011; Spokane. Edited by McCloskey B. Red Hook, New York: Western Society of Weed Science; 2011:103.

9. Zapiola ML, Mallory-Smith CA: Crossing the divide: gene flow produces intergeneric hybrid in feral transgenic creeping bentgrass population. Mol Ecol 2012, 21(19):4672-4680.

10. Belanger FC, Meagher TR, Day PR, Plumley K, Meyer WA: Interspecific hybridization between and related species under field conditions. Crop Sci 2003, 43(1):240-246.

11. Wipff JK: Gene flow in turf and forage grasses (Poaceae). In Proceedings of Scientific Methods Workshop: Ecological and Agronomic Consequences of Gene Flow from Transgenic Crops to Wild Relatives: March 5-6 2002; Columbus, Ohio. Edited by Spencer L. Columbus: Ohio State University; 2002:143-161. 
12. Wipff JK, Fricker C: Gene flow from transgenic creeping bentgrass (Agrostis stolonifera L.) in the Willamette Valley, Oregon. Int Turfgrass Soc Res J 2001, 9:224-242.

13. Pfender W, Graw R, Bradley W, Carney M, Maxwell L: Emission rates, survival, and modeled dispersal of viable pollen of creeping bentgrass. Crop Sci 2007, 47(6):2529-2539.

14. Mallory Smith C, Zapiola M: Gene flow from glyphosate-resistant crops. Pest Manag Sci 2008, 64(4):428-440.

15. Young WT: Grass Seed Production in Oregon. [http://cropandsoil.oregonstate. edu/seed-ext/Pub/or_prod.html]

16. Wegier A, Pineyro Nelson A, Alarcon J, Gálvez Mariscal A, Alvarez Buylla ER, Piñero D: Recent long-distance transgene flow into wild populations conforms to historical patterns of gene flow in cotton (Gossypium hirsutum) at its centre of origin. Mol Ecol 2011, 20(19):4182-4194.

17. James C: Global Status of Commercialized Biotech/GM Crops: 2011. Ithaca: International Service for the Acquisition of Agri-Biotech Applications (ISAAA); 2012.

18. Heuberger S, Ellers-Kirk C, Tabashnik BE, Carrière Y: Pollen- and seed-mediated transgene flow in commercial cotton seed production fields. Plos One 2010, 5(11):e14128

19. Llewellyn DJ, Tyson C, Constable GA, Duggan B, Beale S, Steel P: Containment of regulated genetically modified cotton in the field. Agr Ecosyst Environ 2007, 121(4):419-429.

20. Rhodes J: Cotton pollination by honeybees. Anim Prod Sci 2002, 42(4):513-518

21. Van Deynze AE, Sundstrom FJ, Bradford KJ: Pollen-mediated gene flow in California cotton depends on pollinator activity. Crop Sci 2005, 45 (4):1565-1570.

22. James C: Global Status of Commercialized Biotech/GM Crops: 2012. Ithaca: International Service for the Acquisition of Agri-Biotech Applications (ISAAA); 2013

23. Friesen $L F$, Nelson $A G$, Van Acker RC: Evidence of contamination of IR (Brassica napus) seedlots in western Canada with genetically engineered herbicide resistance traits. Agron J 2003, 95(5):1342-1347.

24. Yoshimura Y, Beckie HJ, Matsuo K: Transgenic oilseed rape along transportation routes and port of Vancouver in western Canada. Environ Biosafety Res 2006, 5(2):67-75.

25. Knispel AL, McLachlan SM, Van Acker RC, Friesen LF: Gene flow and multiple herbicide resistance in escaped canola populations. Weed Sci 2008, 56(1):72-80.

26. Knispel AL, McLachlan SM: Landscape-scale distribution and persistence of genetically modified oilseed rape (Brassica napus) in Manitoba. Canada Environ Sci Pollut R 2010, 17(1):13-25.

27. Aono M, Wakiyama S, Nagatsu M, Kaneko Y, Nishizawa T, Nakajima N, Tamaoki M, Kubo A, Saji H: Seeds of a possible natural hybrid between herbicide-resistant Brassica napus and Brassica rapa detected on a riverbank in Japan. GM Crops 2011, 2(3):201-210.

28. Kawata M, Murakami K, Ishikawa T: Dispersal and persistence of genetically modified oilseed rape around Japanese harbors. Environ Sci Pollut R 2009, 16(2):120-126.

29. Nishizawa T, Tamaoki M, Aono M, Kubo A, Saji H, Nakajima N: Rapeseed species and environmental concerns related to loss of seeds of genetically modified oilseed rape in Japan. GM Crops 2010, 1(3):143-156.

30. Simard MJ, Légère A, Warwick SI: Transgenic Brassica napus fields and Brassica rapa weeds in Québec: sympatry and weedcrop in situ hybridization. Can J Botany 2006, 84(12):1842-1851.

31. Warwick SI, Legere A, Simard MJ, James T: Do escaped transgenes persist in nature? The case of an herbicide resistance transgene in a weedy Brassica rapa population. Mol Ecol 2008, 17(5):1387-1395.

32. Warwick SI, Simard MJ, Legere A, Beckie HJ, Braun L, Zhu B, Mason P, Seguin Swartz G, Stewart CN: Hybridisation between transgenic Brassica napus L. and its wild relatives: Brassica rapa L., Raphanus raphanistrum L., Sinapsis arvensis L., and Erucastrum gallicum (Willd.) O.E. Schulz. Theor Appl Genet 2003, 107(3):528-539.

33. Organisation for Economic Co-operation and Development (OECD): Consensus document on the biology of Brassica crops (Brassica spp.). In Series on Harmon isation of Regulatory Oversight in Biotechnology. Volume 54. Edited by OECD. Paris: OECD; 2012.

34. Saji $H$, Nakajima $N$, Aono $M$, Tamaoki M, Kubo A, Wakiyama S, Hatase $Y$, Nagatsu M: Monitoring the escape of transgenic oilseed rape around Japanese ports and roadsides. Environ Biosafety Res 2005, 4(4):217-222.
35. Aono M, Wakiyama S, Nagatsu M, Nakajima N, Tamaoki M, Kubo A, Saji H: Detection of feral transgenic oilseed rape with multiple-herbicide resistance in Japan. Environ Biosafety Res 2006, 5(2):77-87.

36. Mizuguti A, Yoshimura Y, Shibaike H, Matsuo K: Persistence of feral populations of Brassica napus originated from spilled seeds around the Kashima seaport in Japan. Japan Agric Res Q 2011, 45(2):181-185.

37. Elling B, Neuffer B, Bleeker W: Sources of genetic diversity in feral oilseed rape (Brassica napus) populations. Basic Appl Ecol 2009, 10(6):544-553.

38. Ezcurra E, Ortiz S, Soberon MJ: Evidence of gene flow from transgenic maize to local varieties in Mexico. In LMOs and the Environment: Proceedings of an International Conference, OECD: November 27-30 2001; Durham, North Carolina. Edited by Roseland CR. Paris: OECD; 2002:289-295.

39. Serratos Hernandez JA, Gomez Olivares JL, Salinas Arreortua N, Buendia Rodriguez E, Islas Gutierrez F, De Ita A: Transgenic proteins in maize in the soil conservation area of Federal District, Mexico. Front Ecol Environ 2007, 5(5):247-252.

40. Mercer $\mathrm{KL}$, Wainwright JD: Gene flow from transgenic maize to landraces in Mexico: an analysis. Agric Ecosyst Environ 2008, 123(1-3):109-115.

41. Piñeyro-Nelson A, Van Heerwaarden J, Perales HR, Serratos-Hernández JA, Rangel A, Hufford MB, Gepts B, Garay-Arroyo A, Rivera-Bustamante R, Álvarez-Buylla ER: Transgenes in Mexican maize: molecular evidence and methodological considerations for GMO detection in landrace populations. Mol Ecol 2008, 18(4):750-761.

42. Schafer MG, Ross AA, Londo JP, Burdick CA, Lee EH, Travers SE, Van de Water PK, Sagers CL: The establishment of genetically engineered canola populations in the US. Plos One 2011, 6(10):e25736.

43. McCauley R, Davies M, Wyntje A: The stepwise approach to adoption of genetically modified (GM) canola in Western Australia. AgBioForum 2012, 15(1):61-69.

44. Conservation Council of Western Australia (CCWA): A Survey of Roadside Fugitive GM (Roundup Ready) Canola Plants at Williams, Western Australia. [http://ccwa.org.au/content/fugitive-gm-canola-study]

45. Squire GR, Breckling B, Dietz Pfeilstetter A, Jorgensen RB, Lecomte J, Pivard $S$, Reuter $H$, Young MW: Status of feral oilseed rape in Europe: its minor role as a GM impurity and its potential as a reservoir of transgene persistence. Environ Sci Pollut Res 2011, 18(1):111-115.

46. Schoenenberger N, D'Andrea L: Surveying the occurrence of subspontaneous glyphosate-tolerant genetically engineered Brassica napus L. (Brassicaceae) along Swiss railways. Environ Sci Eur 2012, 24(1):1-8.

47. D'Hertefeldt T, Jørgensen RB, Pettersson LB: Long-term persistence of GM oilseed rape in the seedbank. Biol Lett 2008, 4(3):314-317.

48. Greenpeace: Genetically Engineered Rice: Illegal and Unwanted in China. [http://www.greenpeace.org.uk/media/reports/genetically-engineered-riceillegal-and-unwanted-in-china]

49. Greenpeace: Illegal GE Rice Contamination Spreads to Major Chinese City. [http://www.greenpeace.org/eastasia/press/releases/food-agriculture/ 2005/20050613_ge_rice_gz_html/]

50. Pearce F: China's GM Trees Get Lost in Bureaucracy. New Sci 2004 [www.newscientist.com/article/dn6402-chinas-gm-trees-get-lost-inbureaucracy.htm]

51. Lu MZ, Chen XL, Hu JJ: Empirical assessment of gene flow from transgenic poplar plantation. In Ninth International Symposium on the Biosafety of Genetically Modified Organisms, Biosafety Research and Environmental Risk Assessment: September 24-29 2006; Jeju Island, South Korea. Edited by Roberts A. Oxford Mills: International Society for Biosafety Research (ISBR); 2006:131-136.

52. Then C, Hamberger S: Genetically Engineered Trees-A Ticking Time Bomb? Testbiotech 2010 [http://www.testbiotech.de/sites/default/files/ 101207_testbiotech_pappeln_en.pdf]

53. Davidson SN: Forbidden fruit: transgenic papaya in Thailand. Plant Physiol 2008, 147(2):487-493.

54. Gepts P: Crop domestication as a long-term selection experiment. In Plant Breeding Reviews. Volume 24. 2nd edition. Edited by Jannick J. Hoboken: Wiley; 2004:1-44.

55. Vigueira CC, Li W, Olsen KM: The role of Bh4 in parallel evolution of hull colour in domesticated and weedy rice. J Evolution Biol 2013, 26(8):1738-1749.

56. Arriola PE, Ellstrand NC: Crop-to-weed gene flow in the genus Sorghum (Poaceae): spontaneous interspecific hybridization between 
johnsongrass, Sorghum halepense, and crop sorghum S. bicolor. Am J Bot 1996, 83(9):1153-1160.

57. Adugna A, Bekele E: Morphology and fitness components of wild $\times$ crop F1 hybrids of Sorghum bicolor (L.) in Ethiopia: implications for survival and introgression of crop genes in the wild poo. Plant Genet Resour Charact Util 2013, 11(3):196-205.

58. Paine JA, Shipton CA, Chaggar S, Howells RM, Kennedy MJ, Vernon G, Wright SY, Hinchliffe E, Adams JL, Silverstone AL, Drake R: Improving the nutritional value of Golden Rice through increased pro-vitamin A content. Nat Biotechnol 2005, 23:482-487.

59. Lu BR, Yang C: Gene flow from genetically modified rice to its wild relatives: assessing potential ecological consequences. Biotechnol Adv 2009, 27(6):1083-1091.

60. Chen LJ, Lee DS, Song ZP, Suh HS, Lu BR: Gene flow from cultivated rice (Oryza sativa) to its weedy and wild relatives. Ann Bot London 2004, 93(1):67-73.

61. Ellstrand NC: Dangerous Liaisons? When Cultivated Plants Mate with Their Wild Relatives. Baltimore: Johns Hopkins University Press; 2003.

62. Ridley CE, Ellstrand NC: Evolution of enhanced reproduction in the hybrid-derived invasive, California wild radish (Raphanus sativus). Biol Invasions 2009, 11:2251-2264

63. Ellstrand NC, Prentice HC, Hancock JF: Gene flow and introgression from domesticated plants into their wild relatives. Annu Rev Ecol Syst 1999, 30:539-563.

64. Arriola PE, Ellstrand NC: Fitness of interspecific hybrids in the genus Sorghum: persistence of crop genes in wild populations. Ecol App/ 1997, 7(2):512-518.

65. Morrell PL, Williams Coplin TD, Lattu AL, Bowers JE, Chandler JM, Paterson AH: Crop-to-weed introgression has impacted allelic composition of johnsongrass populations with and without recent exposure to cultivated sorghum. Mol Ecol 2005, 14(7):2143-2154.

66. Kwit C, Moon HS, Warwick SI, Stewart CN Jr: Transgene introgression in crop relatives: molecular evidence and mitigation strategies. Trends Biotechnol 2011, 29(6):284-293.

67. Lu BR: Introgression of transgenic crop alleles: its evolutionary impacts on conserving genetic diversity of crop wild relatives. J Syst Evol 2013, 51(3):245-262

68. Snow AA, Andow DA, Gepts P, Hallerman EM, Power A, Tiedje JM, Wolfenbarger LL: Genetically engineered organisms and the environment: current status and recommendations. Ecol Appl 2005, 15(2):377-404.

69. Bundesamt für Naturschutz (BfN): Gebietsfremde Arten: Positionspapier des Bundesamtes für Naturschutz, BfN-Skripten 128. Bonn; 2005.

70. Clements DR, Ditommaso A: Climate change and weed adaptation: can evolution of invasive plants lead to greater range expansion than forecasted? Weed Res 2011, 51(3):227-240.

71. Meyer P, Linn F, Heidmann I, Meyer H, Niedenhof I, Saedler H: Endogenous and environmental factors influence $35 \mathrm{~S}$ promoter methylation of a maize A1 gene construct in transgenic petunia and its colour phenotype. Mol Genes Genet 1992, 231:345-352.

72. Matthews D, Jones H, Gans P, Coates S, Smith LM: Toxic secondary metabolite production in genetically modified potatoes in response to stress. J Agr Food Chem 2005, 53(20):7766-7776.

73. Zeller SL, Kalinina O, Brunner S, Keller B, Schmid B: Transgene $\times$ environment interactions in genetically modified wheat. Plos One 2010, 5(7):e11405.

74. Breckling B: Transgenic evolution and ecology are proceeding. In GMCrop Cultivation-Ecological Effects on a Landscape Scale. Edited by Breckling B, Verhoeven R. Frankfurt: Peter Lang; 2013:130-135.

75. Mercer KL, Andow DA, Wyse DL, Shaw RG: Stress and domestication traits increase the relative fitness of crop-wild hybrids in sunflower. Ecol Lett 2007, 10(5):383-393.

76. Franks SJ, Weis AE: Climate change alters reproductive isolation and potential gene flow in an annual plant. Evol Appl 2009, 2(4):481-488.
77. Commission E: Regulation (EC) No 1830/2003 of the European Parliament and of the Council of 22 September 2003 concerning the traceability and labelling of genetically modified organisms and the traceability of food and feed products produced from genetically modified organisms and amending Directive 2001/18/EC. Off J Eur Commun L 2003, 268:24-28.

78. Krämer L: Genetically Modified Living Organisms and the Precautionary Principle. [http://www.testbiotech.de/node/904]

79. EFSA European Food Safety Authority: Guidance on the environmental risk assessment of genetically modified plants. EFSA J 2010, 8(11):1879.

doi:10.1186/2190-4715-25-34

Cite this article as: Bauer-Panskus et al:: Cultivation-independent establishment of genetically engineered plants in natural populations: current evidence and implications for EU regulation. Environmental Sciences Europe 2013 25:34

\section{Submit your manuscript to a SpringerOpen ${ }^{\odot}$ journal and benefit from:}

- Convenient online submission

- Rigorous peer review

- Immediate publication on acceptance

- Open access: articles freely available online

- High visibility within the field

- Retaining the copyright to your article

Submit your next manuscript at $\gg$ springeropen.com 